\title{
Foreword: 2Pac's Legacy From the Hip-Hop Platform
}

\author{
Michael Eric Dyson \\ Georgetown University
}

There will never be another Tupac. That is Tupac, in one fatal swoop and one rhetorical gesture, he both acknowledges the centrality of his mother's beauty while also saying that she was flawed. Even as a crack fiend mama. Ya always was a black Queen mama. Who da think in Elementary. Hey, I'd see the penitentiary one day. So, Tupac was able ... something about that voice registered beautifully that intimately spoke to you. Like the Marvin Gaye of hip-hop, you could feel the painful stuff and the channeling of that desire. You could feel his hurt and anguish. It was not about making money; even though he was rich, he knew he was doing it for the love of the "Yeoman," to tell the truth and to register his beliefs in America. He wanted to leave his imprint. He wanted to leave some kind of recognition of those BROTHAs who would never be acknowledged by anybody. He said, "Tupac cares, if don't nobody else care."

So, the beauty of Tupac is that he represents the expressions and the ultimate symbol of Black masculinity and Black culture in general arguing against the odds. Yes, he was self-destructive. Yes, he shredded the line between representation and reality. Yes, he could have grown up. He was only 25 when he died. What were you doing at 25 ? He had written over 400 songs and made six films when he died at 25 years old. The man was working out his soul salvation in full public view.

What I love about Tupac was his obsession with God. Tupac saw that people worshiped their narrow notions of who God is. God is too big for your theological categories. Tupac said, "I am searching for black Jesus." He said, "Somebody that hurt like we hurt, drink like we drink, and smoke like we smoke. A saint we can pray to in the Ghetto." Now, you might say, "What kind of God is this? Smoking weed and drinking some drinks." What he is trying to say is that we are looking for somebody who been through what we have been through.

Last time I checked, Christians, they got a God who became a human being and therefore struggled with human beings, endured the sin of the world, took it on, and absolved them of human responsibility by dying for these sins because he became like them. That is all Tupac said, "I am looking for a black Jesus that understands the internal dynamics of my suffering." That is why he said, "Somebody help me! Tell me where to go from here! Even thugs cry. But do the Lord can?" So, he raised the question of God's care for the world and he answered it even in the midst of his questioning by asking, "If Heaven's got a G, proclaiming Heaven does have a heaven for it. Heaven does have space for a $\mathrm{G}$, a ghetto, a thug. Is there a heaven for a G? Is there a heaven for thugs?" He was constantly questioning; will God forgive me? He was like the

Dyson (med52@georgetown.edu) is with the Department of Sociology, Georgetown University, Washington, DC, USA.
Psalmist. If you read the Psalms, on the one hand: Against thee, thee only, have I sinned, and done this evil in thy sight O Lord. Then, at the same time hey, by the way, kill my enemies too, break them off too, kill their mamas, and destroy their houses.

Oh, and David, by the way, he was like, you know, I am going to go send the husband of this woman I am trying to Mac to the front war so I can have his woman. Do not tell me about no gangster rap - that is all in the song. Tupac is a ghetto saint, some people do not think he is dead. He is the first character to integrate immortality from our community to that exclusive pantheon of figures such as John F. Kennedy and Elvis Presley, who are deemed by their fans and followers to be still alive. I was down in Jamaica, and they said, "The man lives, you know, my man is right down the island." I said, "Don't take me to him, love that brother, but I am trying to write a book."

Some young people cannot believe Tupac is dead because they have so identified with his body: beautiful, young, handsome, expressive, and articulate, that for him to die is for us to die. Our identification means that we are vulnerable too. We forestall all that possibility by believing in his immortality, or at least his joke on the grand block. His big joke on America, imitating Machiavelli who said, "That you ought to fake your own death in order to hold on the power."

Others believe that he is alive in their hearts because his spirit continues to exist in a beautiful way. See, Tupac now was an urban legend and to celebrate Tupac is to judge and critique the society that made thug life necessary. In other words, when we celebrate him, we are saying to America, we do not listen to you telling us not to like him. We like him to judge you. He is a saint because some people invest in him, a kind of almost deification. An elevation to a status of a saint. Chanting his name, using his lyrics as rosary beads to grasp hold of, articulating his poetic vision of pain, as a sermon to our song.

So, for me, Tupac represents all this beautiful, contradictory, utterly self-destructive, edifying, hopeless, and hopeful-which is why he is the most complete symbol of a generation still evolving.

\section{Author Biography}

Michael Eric Dyson is Professor of Sociology at Georgetown University, a New York Times contributing opinion writing, and a contributing editor of The New Republic and of ESPN's The Undefeated website. He is the author and editor of more than two dozen books, including Making Malcolm: The Myth and Meaning of Malcolm X (Oxford University Press, 1995), Reflecting Black: African American Cultural Criticism (University of Minnesota Press, 1993), JAY-Z: Made in America (St. Martin's Press, 2019), The Black Presidency: Barack Obama and the Politics of Race in America (Houghton Mifflin Harcourt, 2016), and Holler if you Hear Me: Searching for Tupac Shakur (Basic, 2002). 